\title{
The larger bronchi in cryptogenic fibrosing alveolitis: a morphometric study
}

\author{
CW EDWARDS, A CARLILE \\ From the Department of Pathology, East Birmingham Hospital, Birmingham
}

ABSTRACT In a morphometric study of the main, lobar, and segmental bronchi of the left lung in nine cases.of cryptogenic fibrosing alveolitis the quantity of gland was found to be significantly greater than in a group $\vec{\infty}_{\infty}^{-}$ of normal controls, and similar to that of a group of patients with chronic bronchitis. The quantity of muscle ${ }_{\infty}^{N}$ was also increased, amounts in the segmental bronchi being higher than in the bronchitic patients. The causeo of these changes is uncertain, but they seem likely to be due to proximal extension of repeated and persistent $\rightarrow$ infection of the lung parenchyma.

In cryptogenic fibrosing alveolitis there is progressive effacement of distal air spaces by fibrous tissue, while at the same time bronchioles and smaller bronchi dilate. Eventually the characteristic end-stage "honeycomb lung" develops. ${ }^{1-4}$ Physiological measurements indicate restrictive and diffusion defects ${ }^{35}$ and sometimes obstruction of small bronchi. ${ }^{6-9}$ The abnormalities in the periphery of the lung are so dramatic that little attention has been paid to the larger airways, even though casual observation of the major bronchi in such cases gives the impression of an increase in glandular and muscular tissue.

We describe a morphometric study of the components of the walls of the main, lobar, and segmental bronchi in nine cases of cryptogenic fibrosing alveolitis examined at necropsy at East Birmingham Hospital.

\section{Cases studied}

Brief clinical details of the nine patients who formed the basis of this study are given in table 1 . All these patients were diagnosed as suffering from cryptogenic fibrosing alveolitis during life, on the basis of criteria similar to those laid down by Turner-Warwick and her co-workers. ${ }^{10}$ Respiratory function tests had been carried out in cases 1 , 3,5 , and 9; these had shown restrictive and diffusion defects, but no evidence of airways obstruction. At necropsy in all the patients there was end-stage honeycomb lung, associated with acute inflammation and suppuration. A small localised peripheral adenocarcinoma was found in cases 3 and 8 . There was extensive parenchymal smooth muscle hyperplasia in case 1 .

There were two control groups. The first consisted of

Address for reprint requests: Dr CW Edwards. Department of Histopathology. East Birmingham Hospital. Birmingham B9 5ST. five patients coming to necropsy who were lifelong non-smokers and who had no clinical or postmortem evidence of respiratory disease. The second group consisted of 18 patients with chronic bronchitis diagnosed during life on the basis of excess mucus production? recurrent chest infections, and airways obstruction of varying severity.

\section{Methods}

In each case the left lung was pressure fixed with formo saline, an apparatus similar to that described by Heard $e t 5$ al being used." After 48 hours' fixation transverse blocks, each about $5 \mathrm{~mm}$ thick, were taken from the lef main bronchus, from the upper and lower lobar bronchi, and from all the named segmental bronchi with the् exception of the anterior segmental bronchus of the uppero lobe. The blocks were processed and embedded in paraffin wax by a conventional technique. Three sectionsi

Table 1 Clinical details of the cases of cryptogenic fibrosing alveolitis studied

\begin{tabular}{|c|c|c|c|c|}
\hline Case No & Age & Sex & $\begin{array}{l}\text { Smoking history } \\
\text { (cigarettes/day) }\end{array}$ & $\begin{array}{l}\text { Duration of } \\
\text { symptoms (y) }\end{array}$ \\
\hline 1 & 43 & $\mathbf{M}$ & $\begin{array}{l}20+ \\
\text { stopped } 4 \text { y }\end{array}$ & 3 \\
\hline 2 & 58 & $\mathbf{M}$ & $\begin{array}{l}20+ \\
\text { stopped } 4 y\end{array}$ & 4 \\
\hline 3 & 67 & $\mathbf{M}$ & $\begin{array}{l}20 \\
\text { stopped } 11 / 2 y\end{array}$ & 4 \\
\hline $\begin{array}{l}4 \\
5 \\
6 \\
7 \\
8\end{array}$ & $\begin{array}{l}69 \\
71 \\
77 \\
58 \\
66\end{array}$ & $\begin{array}{l}\mathbf{M} \\
\mathbf{M} \\
\mathbf{M} \\
\mathrm{F} \\
\mathrm{F}\end{array}$ & $\begin{array}{l}\mathrm{Nil} \\
\mathrm{Nil} \\
\mathrm{Nil} \\
\mathrm{Nil} \\
10\end{array}$ & $\begin{array}{l}4 \\
1 \\
1 / 2 \\
2\end{array}$ \\
\hline 9 & 76 & $\mathbf{F}$ & $\begin{array}{l}\text { stopped } 1 \text { y } \\
\text { Nil }\end{array}$ & $\begin{array}{l}12 \\
2\end{array}$ \\
\hline
\end{tabular}


$5 \mu \mathrm{m}$ in thickness and about $1 \mathrm{~mm}$ apart were cut from each block and stained with haematoxylin and eosin.

The cross-sectional area of the bronchial wall and the areas occupied by gland, muscle, and cartilage were then measured by means of a projecting microscope and a Reichert-Jung electronic planimeter. The periphery of the bronchus was taken to be a line following the outer surface of the perichondrium or an extrapolation of this line where the cartilage was absent.

The proportions of the components of the bronchial wall were expressed as a percentage of the total cross-sectional area. Statistical analysis was carried out with the aid of a Commodore Pet Computer. Differences were tested with Student's $t$ test for paired and unpaired data.

\section{Results}

\section{MORPHOMETRY}

The amount of bronchial cartilage was the same in all three groups, whereas bronchial muscle and gland were often increased in the patients with chronic bronchitis or fibrosing alveolitis. The percentages of gland and muscle in the individual bronchi are shown in fig $1(a-e)$. Means and standard deviations are given in table 2 .

The mean percentage of gland in the patients with fibrosing alveolitis was significantly higher than in the normal subjects ( $\mathrm{p}<0.05$ at all sites). As expected, there was also a significant increase in the mean percentage of gland in the patients with chronic bronchitis $(\mathrm{p}<0.01$ at all sites). The mean percentage of gland was essentially the same in the chronic bronchitic and the fibrosing alveolitis groups (table 2).

In the fibrosing alveolitis group the mean percentage of muscle was significantly higher than in the normal

Table 2 Mean percentages $( \pm S D)$ of gland and muscle in the bronchi of the three groups

\begin{tabular}{|c|c|c|c|c|}
\hline & & Normal & $\begin{array}{l}\text { Chronic } \\
\text { bronchitis }\end{array}$ & $\begin{array}{l}\text { Fibrosing } \\
\text { alveolitis }\end{array}$ \\
\hline $\begin{array}{l}\text { Main left } \\
\text { bronchus }\end{array}$ & $\begin{array}{l}\text { Gland } \\
\text { Muscle }\end{array}$ & $\begin{array}{l}6 \cdot 74(1 \cdot 8) \\
0.97(0.9)\end{array}$ & $\begin{array}{r}19 \cdot 2(6 \cdot 8) \\
2 \cdot 1(1 \cdot 1)\end{array}$ & $\begin{array}{l}15 \cdot 7(7 \cdot 1)^{*} \\
2 \cdot 1(1 \cdot 1)\end{array}$ \\
\hline $\begin{array}{l}\text { Upper lobe } \\
\text { bronchus }\end{array}$ & $\begin{array}{l}\text { Gland } \\
\text { Muscle }\end{array}$ & $\begin{array}{l}8 \cdot 4(2 \cdot 7) \\
0 \cdot 74(0 \cdot 5)\end{array}$ & $\begin{array}{r}20 \cdot 2(7 \cdot 5) \\
2 \cdot 7(1 \cdot 7)\end{array}$ & $\begin{array}{r}16 \cdot 0(6 \cdot 6)^{*} \\
2 \cdot 3(1 \cdot 1)^{*}\end{array}$ \\
\hline $\begin{array}{l}\text { Lower lobe } \\
\text { bronchus }\end{array}$ & $\begin{array}{l}\text { Gland } \\
\text { Muscle }\end{array}$ & $\begin{array}{l}8 \cdot 1(1 \cdot 3) \\
1 \cdot 5(0 \cdot 4)\end{array}$ & $\begin{array}{r}16 \cdot 2(5 \cdot 2) \\
2 \cdot 6(1 \cdot 8)\end{array}$ & $\begin{array}{c}16 \cdot 6(7 \cdot 6)^{*} \\
4 \cdot 0(1 \cdot 7)^{*}\end{array}$ \\
\hline $\begin{array}{l}\text { Segmental bronchi } \\
\text { upper lobe }\end{array}$ & $\begin{array}{l}\text { Gland } \\
\text { Muscle }\end{array}$ & $\begin{array}{l}6 \cdot 1(1 \cdot 9) \\
0 \cdot 6(0 \cdot 1)\end{array}$ & $\begin{array}{r}16 \cdot 4(7 \cdot 4) \\
1 \cdot 4(0 \cdot 9)\end{array}$ & $\begin{array}{l}15 \cdot 4(8 \cdot 3)^{*} \\
2 \cdot 3(0 \cdot 9)^{* \ddagger}\end{array}$ \\
\hline $\begin{array}{l}\text { Segmental bronchi } \\
\text { lower lobe }\end{array}$ & $\begin{array}{l}\text { Gland } \\
\text { Muscle }\end{array}$ & $\begin{array}{l}6 \cdot 2(0 \cdot 9) \\
0 \cdot 6(0 \cdot 1)\end{array}$ & $\begin{array}{r}15 \cdot 8(6 \cdot 5) \\
1 \cdot 4(0 \cdot 9)\end{array}$ & $\begin{array}{l}13 \cdot 5(5 \cdot 6)^{*} \\
2 \cdot 5(1 \cdot 9)^{* \dagger}\end{array}$ \\
\hline
\end{tabular}

*Fibrosing alveolitis significantly different from normal $(p<0.05)$. †Fibrosing alveolitis significantly different from chronic bronchitis $(\mathrm{p}<$ 0.05 ).

$\ddagger$ Fibrosing alveolitis significantly different from chronic bronchitis $(\mathrm{p}<$ $0 \cdot 025$ ). subjects $(p<0.05)$ at all sites except one. The exception was in the main left bronchus, where, although the mean was higher in the fibrosing alveolitis group, the difference was not significant $(p<0 \cdot 1)$. The mean percentage of muscle in the segmental bronchi of the upper and lower lobes of the fibrosing alveolitis group was also significantly higher than in the chronic bronchitic group ( $<<0.025$ and 0.05 respectively). There was, however, no statistical difference in the mean percentage of muscle in the main and lobar bronchi of the two groups.

The quantity of muscle in individual bronchitic patients varied widely, and there was considerable overlap with the normal subjects (fig 1). Although the mean percentages of muscle were much higher than normal in the chronic bronchitic group as a whole, the main bronchus was the only site where the increase reached significance $(\mathrm{p}<$ $0 \cdot 05$ ).

When the fibrosing alveolitis group was divided into two according to smoking habits (table 3 ), we found that in both subgroups the mean percentages of gland and, except for the left main bronchi, the mean percentages of muscle were still significantly higher than normal $(p<$ $0 \cdot 05$ ). The quantity of gland and muscle in the bronchi of the ex-smokers was slightly higher than in the nonsmokers, but not significantly so.

Finally, the percentages of the various components varied according to site-for instance, there was more muscle in the lower lobe bronchus than in the upper lobe bronchus in the normal subjects and in the patients with fibrosing alveolitis, but not in the patients with chronic bronchitis (table 2). This aspect of the study is outside the scope of the present paper, and will be dealt with elsewhere.

\section{Histology}

Histologically, the changes in the bronchus of the patients with fibrosing alveolitis were similar to those of chronic bronchitis. There was an increase in bronchial smooth muscle and gland (fig 2), but no other abnormality was

Table 3 Mean percentages ( $\pm S D$ ) of gland and muscle in the ex-smokers and non-smokers with fibrosing alveolitis

\begin{tabular}{|c|c|c|c|}
\hline & & Ex-smokers & Non-smokers \\
\hline $\begin{array}{l}\text { Main left } \\
\text { bronchus }\end{array}$ & $\begin{array}{l}\text { Gland } \\
\text { Muscle }\end{array}$ & $\begin{array}{r}19 \cdot 0(5 \cdot 3) \\
2 \cdot 3(1 \cdot 0)\end{array}$ & $\begin{array}{r}13 \cdot 0(7 \cdot 8) \\
2 \cdot 1(1 \cdot 2)\end{array}$ \\
\hline $\begin{array}{l}\text { Upper lobe } \\
\text { bronchus }\end{array}$ & $\begin{array}{l}\text { Gland } \\
\text { Muscle }\end{array}$ & $\begin{array}{r}16 \cdot 9(6 \cdot 9) \\
2 \cdot 9(1 \cdot 1)\end{array}$ & $\begin{array}{r}15 \cdot 3(7 \cdot 2) \\
1 \cdot 9(0 \cdot 8)\end{array}$ \\
\hline $\begin{array}{l}\text { Lower lobe } \\
\text { bronchus }\end{array}$ & $\begin{array}{l}\text { Gland } \\
\text { Muscle }\end{array}$ & $\begin{array}{r}19 \cdot 2(7 \cdot 7) \\
5 \cdot 0(1 \cdot 6)\end{array}$ & $\begin{array}{r}14 \cdot 5(7 \cdot 8) \\
3 \cdot 0(1 \cdot 4)\end{array}$ \\
\hline $\begin{array}{l}\text { Segmental bronchi } \\
\text { upper lobe }\end{array}$ & $\begin{array}{l}\text { Gland } \\
\text { Muscle }\end{array}$ & $\begin{array}{r}20 \cdot 4(9 \cdot 8) \\
2 \cdot 6(0 \cdot 8)\end{array}$ & $\begin{array}{r}11 \cdot 3(4 \cdot 5) \\
2 \cdot 1(0 \cdot 9)\end{array}$ \\
\hline $\begin{array}{l}\text { Segmental bronchi } \\
\text { lower lobe }\end{array}$ & $\begin{array}{l}\text { Gland } \\
\text { Muscle }\end{array}$ & $\begin{array}{r}14 \cdot 6(7 \cdot 1) \\
3 \cdot 5(2 \cdot 4)\end{array}$ & $\begin{array}{r}12 \cdot 6(4 \cdot 7) \\
1 \cdot 8(1 \cdot 1)\end{array}$ \\
\hline
\end{tabular}




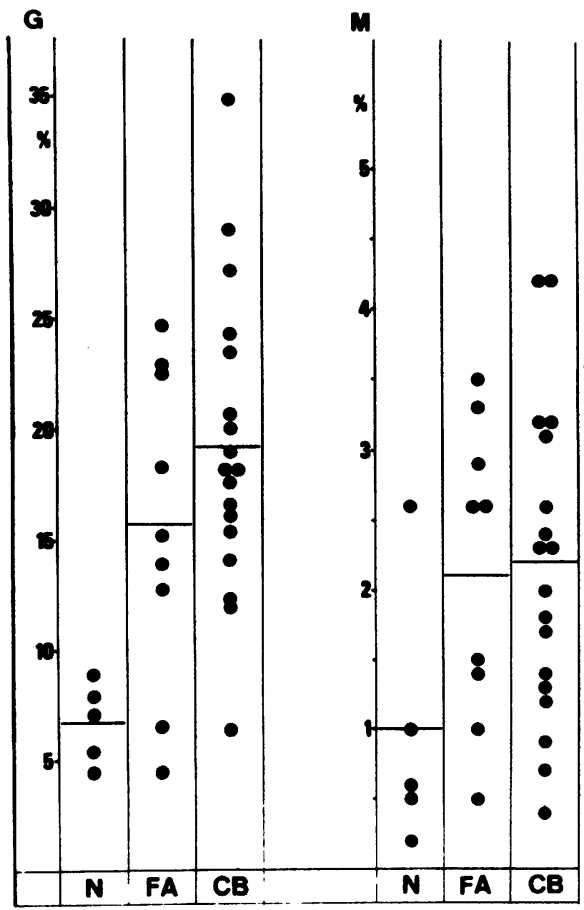

Fig la

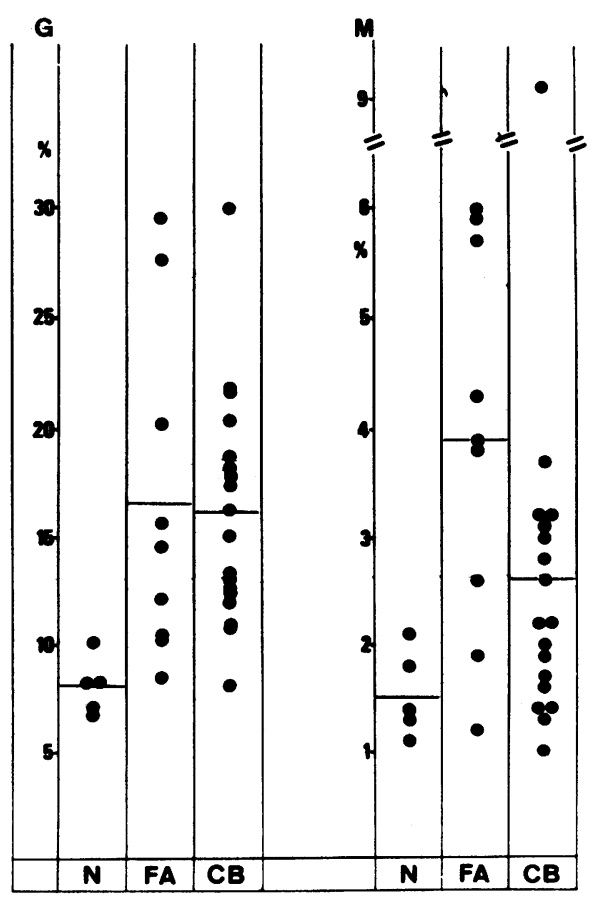

Fig lc

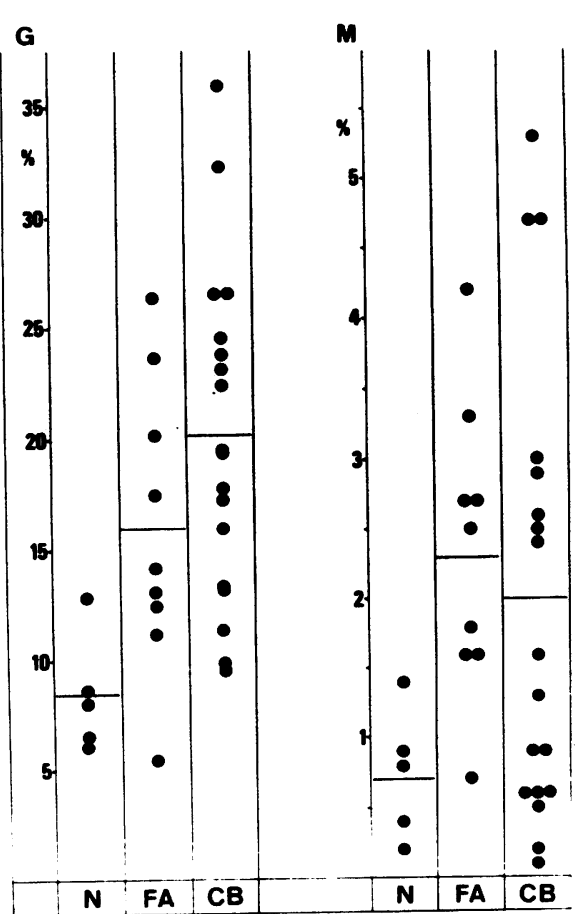

Fig $1 b$

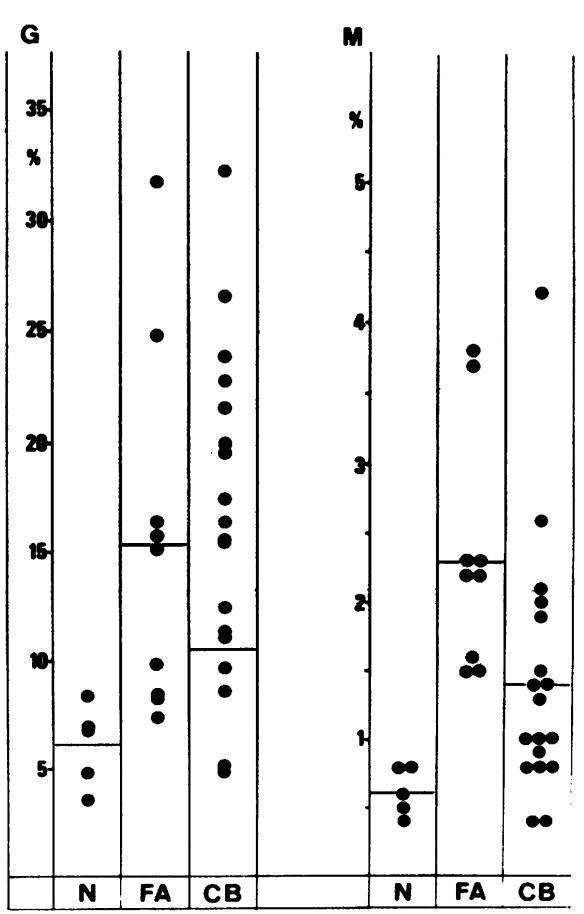

Fig 1d

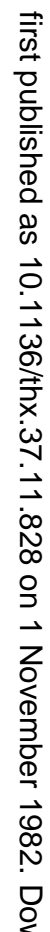

응

음

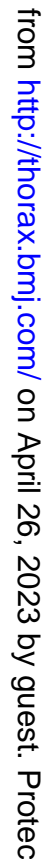




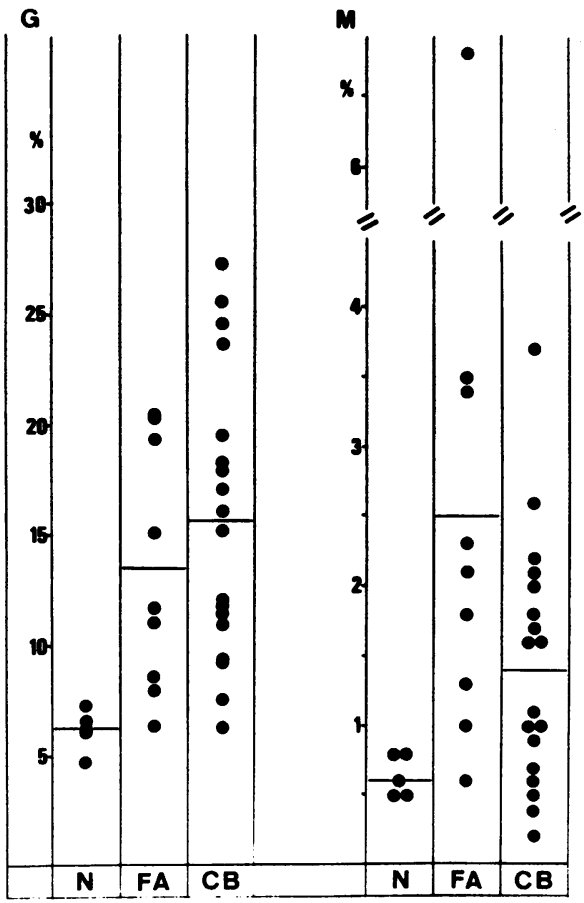

Fig 1 Percentages of gland and muscle at the sites studied in the normal, chronic bronchitis, and cryptogenic fibrosing alveolitis groups: (a) main left bronchus: (b) main upper lobe bronchus; (c) main lower lobe bronchus; (d) segmental bronchi of the upper lobe (mean values): (e) segmental bronchi of the lower lobe (mean values). $G$ - gland; $M$ - muscle; $N$-normal; $C B-$ chronic bronchitis; FA - fibrosing alveolitis.

Fig le
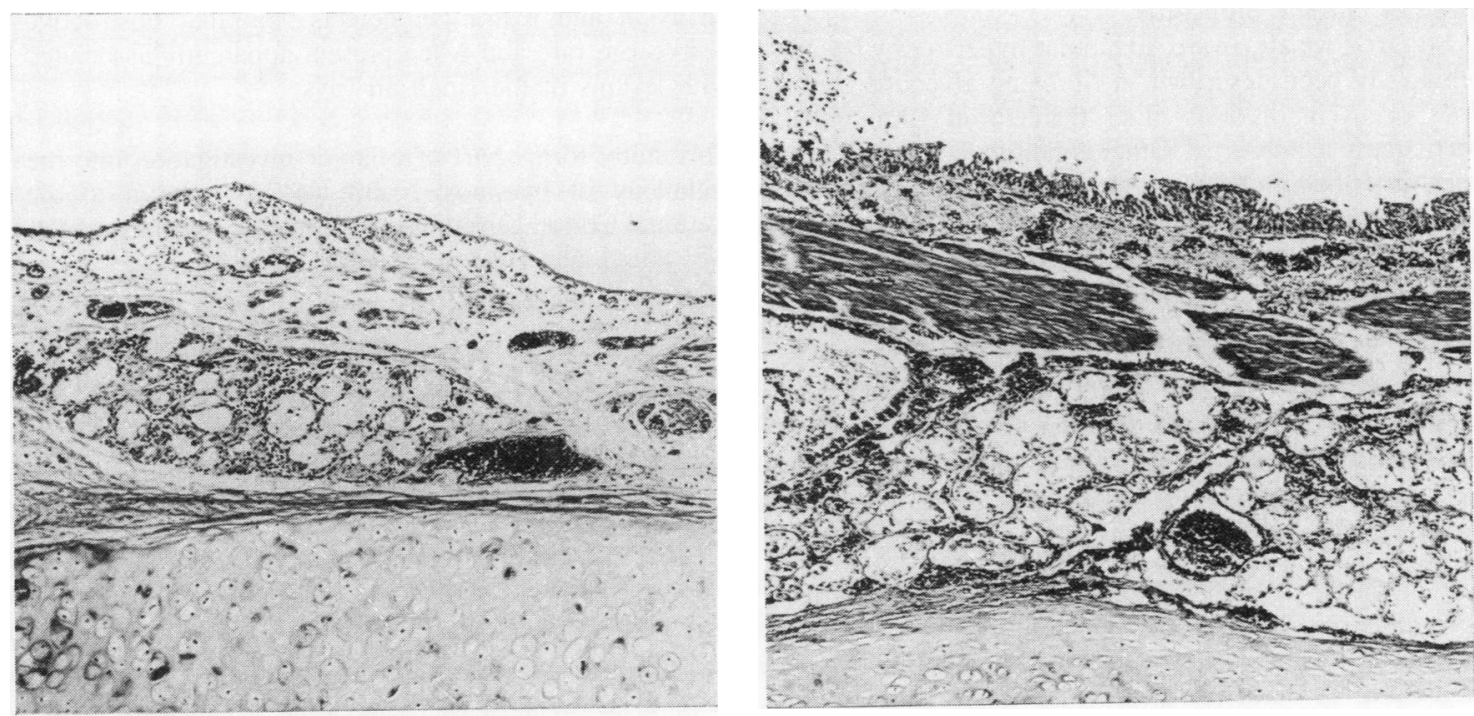

Fig 2 Normal bronchus (left) and bronchus from a patient with (ryptogenic fibrosing alveolitis (right) showing a striking increase in gland and muscle (haematoxylin and eosin. $\times 32$ ). 
consistently seen. The bronchial epithelium was sometimes absent; when present it either was normal or showed patchy squamous metaplasia. There was often irregular thickening of the basement membrane. In some patients there was acute inflammation of the lamina propria, and in others a scanty infiltrate of lymphocytes; in one case there was a moderately dense lymphocytic infiltrate in the subepithelial connective tissue, but no lymphoid follicles were present. No eosinophils were seen in any of the bronchi examined. The cartilage was normal apart from occasional focal areas of calcification.

\section{Discussion}

The percentages of bronchial mucous gland in our normal and chronic bronchitic groups are similar to those quoted by other authors. ${ }^{12-16}$ On the other hand, figures given in published reports for the percentage of bronchial muscle are generally higher than ours: they vary from $1.4 \%$ to $4.6 \%$ for normal subjects, ${ }^{12-14}$ rising to $11.9 \%$ in asthmatics. ${ }^{16-18}$ There are two possible explanations for this. Firstly, in the past point-counting techniques rather than planimetry have been used, and point counting is inaccurate when the component under investigation is only a small percentage of the whole. ${ }^{19}$ Secondly, the percentage of muscle varies according to site (table 2), and previous workers have concentrated on only two or three bronchi whereas we have studied 10 in each case. Nevertheless, despite this disagreement with previously published figures, our investigation clearly shows that there is an increase in both mucous gland and muscle in the larger bronchi of patients with cryptogenic fibrosing alveolitis, resulting in pathological changes identical to those of chronic bronchitis.

So far as we are aware, glandular hypertrophy has not previously been described in fibrosing alveolitis, but it does occur in diseases other than chronic bronchitis, particularly asthma. ${ }^{12} 18$ Other conditions in which it has been described include bronchopneumonia, lung cancer, pneumoconiosis, and bronchiectasis. ${ }^{20-22}$ Thurlbeck explains glandular hypertrophy in bronchiectasis on the basis of pre-existing chronic bronchitis, cigarette smoking, exposure to dust, and an unfavourable socioeconomic environment ${ }^{22}$; in bronchiectasis it seems to be due to proximal extension of infection and inflammation. Thurlbeck is also of the opinion that mucous gland hypertrophy may occur fairly quickly as a terminal event.

Hyperplasia of bronchial muscle is one of the characteristic lesions of asthma, ${ }^{12}$ is 2.3 where it is probably related to bronchospasm. Its place in chronic bronchitis is less clearcut. Morphometric studies based on point counting have shown that although the percentage of muscle is usually normal it is sometimes much increased. ${ }^{1213{ }^{18}}$ Such an increase is found in patients with chronic bronchitis who have episodes of wheezing - the so-called "asthmatic bronchitics." ${ }^{18}$ Using absolute measurements of area rather than percentages. Hossain and Heard found that bronchial smooth muscle was doubled in patients with chronic bronchitis. ${ }^{24}$ In our control series some of the bronchitic patients had increased bronchial muscle whereas others did not. The percentage of muscle in the group as a whole was higher than in the normal subjects, but because of the wide individual variation the difference did not reach significance. Clearly, the whole question of bronchial muscle in chronic bronchitis requires further investigation.

The cause of the increase in muscle and gland in cryptogenic fibrosing alveolitis is uncertain. Pre-existing chronic bronchitis as a factor seems unlikely: there was no history of this condition in any of our cases; and furthermore five of the patients had never smoked, while the other four had given up at least a year before death. These changes also seem unlikely to be due to the effects of an inhaled antigen, although the muscular hyperplasia is reminiscent of asthma. Recurrent and persistent pulmonary infections, however, are a feature of fibrosing alveolitis in its terminal stage, and in all our cases there was acute inflammation and suppuration in the lung parenchyma at necropsy. Probably therefore, as in bronchiectasis, the glandular hypertrophy is the result of extension of infection into the central bronchi. The muscular hyperplasia may also be a reactive change of a similar nature.

Although the pathological changes are striking their clinical significance is doubtful, except perhaps in the terminal stages. In our cases, where the appropriate tests had been carried out there was no physiological evidence of an obstructive defect. Moreover, published data on the physiology of fibrosing alveolitis indicate that there are diffusion and restrictive defects, but that obstructive defects are rare and when present apparently associated with lesions of the small airways. ${ }^{3}$ 5-9

This study forms part of a larger investigation into the pathology of byssinosis, and we are grateful to the National Cotton Corporation of America for its support. We would also like to thank Mrs Ruth Fry for her secretarial help.

\section{References}

${ }^{\prime}$ Fraire AE, Greenberg SD, O'Neal RM. Weg JG. Jenkins DE. Diffuse interstitial fibrosis of the lung. Am J Clin Pathol 1973;59:636-47.

2 Patchefsky AS, Israel HL, Hoch WS, Gordon G. Desquamative interstitial pneumonia: relationship to interstitial fibrosis. Thorax 1973:28:680-93.

${ }^{3}$ Crystal RG, Fulmer JD, Roberts WC, Moss ML, Line BR, Reynolds HY. Idiopathic pulmonary fibrosis: clinical, $\overline{0}$ histologic, radiographic. physiologic, scintigraphic. cytolo- $\overrightarrow{\mathbb{D}}$ gic and biochemical aspects. Ann Intern Med 1976;85:76988 
${ }^{4}$ Crystal RG, Gadek JE, Ferrans VJ, Fulmer JD, Line BR, Hunninghake GW. Interstitial lung disease: current concepts of pathogenesis, staging and therapy. Am J Med 1981;70:542-68.

${ }^{5}$ Collins FF, Sieker HO. Fibrosing alveolitis. DM1978;24:135.

${ }^{6}$ Ostrow D, Cherniack RM. Resistance to airflow in patients with diffuse interstitial lung disease. Am Rev Respir Dis 1973;108:205-10.

${ }^{7}$ Fulmer JD, Roberts WC, Von Gal ER, Crystal RG. Small airways in idiopathic pulmonary fibrosis: comparison of morphologic and physiologic observations. J Clin Invest 1977;60:595-610.

${ }^{8}$ Fulmer JD, Roberts WC. Small airways and interstitial pulmonary disease. Chest 1980;77:470-2.

${ }^{9}$ McCarthy DS, Ostrow DN, Hershfield ES. Chronic obstructive pulmonary disease following idiopathic pulmonary fibrosis. Chest 1980;77:473-7.

${ }^{10}$ Turner-Warwick M, Burrows B, Johnson A. Cryptogenic fibrosing alveolitis: clinical features and their influence on survival. Thorax 1980;35:171-80.

${ }^{11}$ Heard BE, Khatchatourov V, Otto H. Putov NV. The morphology of emphysema, chronic bronchitis, and bronchiectasis: definition, nomenclature, and classification. $J$ Clin Pathol 1979;32:882-92.

12 Dunnill MS, Massarella GR. Anderson JA. A comparison of the quantitative anatomy of the bronchi in normal subjects. in status asthmaticus, in chronic bronchitis and in emphysema. Thorax 1969;24:176-9.

${ }^{13}$ Takizawa T, Thurlbeck WM. A comparative study of four methods of assessing the morphologic changes in chronic bronchitis. Am Rev Respir Dis 1971:103:774-83.
${ }^{14}$ Niewoehner DE, Kleinerman J, Knoke JD. Regional chronic bronchitis. Am Rev Respir Dis 1972;105:586-93.

15 Scott KWM. An autopsy study of bronchial mucous gland hypertrophy in Glasgow. Am Rev Respir Dis 1973;107:23945.

${ }^{16}$ Oberholzer M, Dalquen P. Huber M, Rohr HP. Stereology, a complement to respiration research; bronchus morphometry, methodology and base line data. Microsc Acta 1977;79:205-23.

${ }^{17}$ Hale FC, Olsen CR. Mickey MR. The measurement of bronchial wall components. Am Rev Respir Dis 1968;98:978-87.

${ }^{18}$ Takizawa T, Thurlbeck WM. Muscle and mucous gland size in the major bronchi of patients with chronic bronchitis, asthma and asthmatic bronchitis. Am Rev Respir Dis 1971;104:331-6.

${ }^{19}$ Lennox B. Observations on the accuracy of point counting including a description of a new graticule. J Clin Pathol 1975;28:99-103.

${ }^{20}$ Reid L. Measurement of the bronchial mucous gland layer: a diagnostic yardstick in chronic bronchitis. Thorax 1960;15:132-41.

21 Field WEH. Davey EN. Reid L. Roe FJC. Bronchial mucous gland hypertrophy: its relation to symptoms and environment. Br J Dis Chest 1966:60:66-80.

22 Thurlbeck WM. Chronic airflow obstruction in lung disease. Philadelphia: WB Saunders, 1976.

${ }^{23}$ Heard BE. Hossain S. Hyperplasia of bronchial muscle in asthma. J Pathol 1973:110:319-31.

${ }^{24}$ Hossain S. Heard BE. Hyperplasia of bronchial muscle in chronic bronchitis. J Pathol 1970:101:171-84. 